DOI No: http://dx.doi.org/10.29228/Joh.51424

Authenticity process is conducted by

Makale Türü: Araştırma makalesi

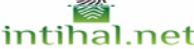

Geliş Tarihi: 16-05-2021

Kabul Tarihi: 25-10-2021

On-line Yayın: 31-10-2021

Article Type: Research article Submitted: 16-05-2021

Accepted: 25-10-2021

Published Online: 31-10-2021

Attf Bilgisi / Reference Information

Sağlam, A., Çiftçi, S. \& Yayla, A. (2021). Opinions of Academicians and Teachers on Lifelong Learning. Journal of History School, 54, 3376-3398.

\title{
OPINIONS OF ACADEMICIANS AND TEACHERS ON LIFELONG LEARNING ${ }^{1}$
}

\author{
Abdulkadir SAĞLAM², Serkan ÇíFTÇi ${ }^{3}$ \& Ahmet YAYLA ${ }^{4}$
}

\begin{abstract}
The aim of the study is to identify the views of academicians and teachers on lifelong learning. The study data, conceived as a case study, was collected using a semi-structured interview module consisting of 6 questions developed by researchers for a total of 15 educators, 5 academics and 10 postgraduate teachers. The data obtained were analyzed by the method of content analysis. According to the results of the study, it was observed that the educators who participated in the study generally displayed a positive attitude towards the sustainability of lifelong learning and they demonstrated that the social and individual effects of lifelong learning can be further increased with educational support, and they stated that steps should be taken to ensure the use of technological developments in educational environments. As teachers and academicians involved in the study

\footnotetext{
${ }^{1}$ This study was presented as an oral presentation at the 8th International Education Programs and Teaching Congress (25-27 March 2021). Author impact rate for article writing: 1 st author: \%35, 2nd: $\% 35,3$ rd \%30. Ethics committee approval of this article was received at Yüzüncü Y1l University with meeting number 2021/05-01.

2 Doctorate, Hacettepe University Institute of Educational Sciences, Department of Primary Education (Basic Education), saglam6888@gmail.com, Orcid:0000-0003-3023-5751

${ }^{3}$ Doctor, Ministry of National Education, serkanciftci65@gmail.com, Orcid: 0000-0003-09491267

${ }^{4}$ Assoc. Dr., Van Yüzüncü Y1l University, Faculty of Education, Department of Educational Sciences, Philosophy of Education, Social and Historical Foundations Department, ahmetyayla@yyu.edu.tr, Orcid: 0000-0002-5021-6649
} 
Opinions of Academicians and Teachers on Lifelong Learning

continue to learn throughout lifelong learning, their responses to interview questions in the study show parallelism. In this context, in our country, in order to raise awareness on lifelong learning in accordance with the needs of the 21 st century, to take steps to ensure that individuals have the skills of the age, and to realize what types of learning will be realized in which periods of their lives according to the needs of individuals for a total development, it is important to gain "lifelong learning literacy".

Keywords: Lifelong Learning, Academician, Teacher, Lifelong Learning Literacy.

\section{Hayat Boyu Öğrenmeye İlişkin Akademisyen ve Öğretmen Görüşleri}

\section{$\ddot{\mathbf{O} z}$}

Araştırmada lisansüstü öğrenime sahip eğitim çalışanlarının hayat boyu öğrenmeye ilişkin görüşlerini ortaya koymak amaçlanmıştır. Durum çalışması olarak desenlenen çalışmada veriler 5'i akademisyen, 10’u ise lisansüstü öğrenime sahip öğretmen olmak üzere toplamda 15 eğitimciden araştırmacılar tarafından geliştirilen ve 6 sorudan oluşan yarı yapılandırılmış görüşme formu ile toplanılmıştır. Elde edilen veriler içerik analizi yöntemiyle analiz edilmiştir. Çalışmanın sonuçlarına göre, çalışmaya katılan eğitimcilerin genel olarak hayat boyu öğrenmenin sürdürülebilirliğine karşı olumlu tavır sergiledikleri ve hayat boyu ögrenmenin toplumsal ve bireysel etkilerinin eğitim desteği ile daha da arttırılabileceğini ortaya koyduklarını vurgulamış, teknolojideki gelişmelerin eğitim ortamlarında da kullanılmasını sağlayacak adımların atılması gerektiğini ifade ettikleri görülmüştür. Araştırmaya katılan öğretmen ve akademisyenler, hayat boyu öğrenmeye devam ettiklerinden, çalışmadaki görüşme sorularına verdikleri yanıtlar paralellik göstermektedir. Bu kapsamda ülkemizde de 21. yy ihtiyaçlarına uygun olarak hayat boyu öğrenme konusunda farkındalık oluşturarak bireylerin çağın becerilerine sahip olmasını sağlayacak adımların atılması gerekliliği belirlenmiştir. Ayrıca topyekûn bir kalkınma için bireylerin ihtiyaçlarına göre hayatlarının farklı dönemlerinde hangi öğrenmeleri gerçekleştireceklerinin bilincinde olmaları adına "hayat boyu öğrenme okuryazarlığgı" nın kazandırılması önem arz etmektedir.

Anahtar Kelimeler: Hayat Boyu Öğrenme, Akademisyen, Öğretmen, Hayat Boyu Öğrenme Okuryazarlığı.

\section{INTRODUCTION}

In the rapidly changing age of information and technology, the need for continuous self-improvement and renewal has emerged in order for individuals to keep up with different situations. Only formal education is not enough to meet the emerging needs (Can, 2011). In the modern world, which has been renewed with constant and rapid change, formal education may be insufficient in terms of both content and format to meet the needs of its contemporary society. One way 
to eliminate this inadequacy is to increase interest in lifelong learning through a process that combines formal, informal and non-formal education. Lifelong learning, sometimes referred to as career-long learning, extends individual learning beyond formal education and training (Burman et al., 2014). In addition to formal education, personal development is also important. For any society to flourish, education must continue throughout life, and individuals must constantly improve themselves throughout their lives (Can, 2011).

In order to keep up with rapid changes in political, social and cultural life according to the needs of the individual's age, the concept of lifelong learning (LLL) has gained importance in terms of education level and employment conditions in developing countries. The UNESCO Commission for the development of education, convened in 1972, decided that education is a lifelong activity (Poyraz \& Titrek, 2013). Lifelong learning is defined as a supportive process that means the acquisition and renewal of all the knowledge, values, skills, competencies and qualities acquired by individuals throughout their lives in the period from birth to death, as well as the application of all this information (Candy, 2003). Lifelong learning is the whole of individual and institutional learning and includes formal learning, non-formal learning, vocational training, technical training, and all in-service and out-of-service training (Jarvis, 2004). However, lifelong learning eliminates the boundaries of concepts such as place, time, age, socio-economic level, educational level and provides equal opportunities for each individual (Dinevski \& Dinevski, 2004). As most general definition, lifelong learning is a form of learning that is flexible, can take place at different times, in different places, and can be maintained throughout life. This learning has a structure that encourages individuals to learn throughout life beyond the usual formal education (Dută \& Rafailă, 2014).

In today's societies, lifelong learning is possible with individuals gaining learning skills (Turan, 2005). Learning to learn, in its simplest form, is an intellectual activity aimed at creating the necessary information for new situations using existing information (Özden, 2002). Educational psychologists define learning and development as a lifelong process that takes place in and out of school within the family, at work, and in other social contexts (Smith \& Pourchot, 1998). People, acquire knowledge and achieve a certain competence from educational institutions, individuals in society, family members, workplaces, etc. in the course of their lives (Kashinath, 2013). People acquire knowledge and enrich their competence by interaction with different social environment throughout their lives. 
Lifelong learning is an ongoing process that develops an individual's competencies and potential throughout their lifetime. This type of learning is not only about learning that takes place throughout the lives of individuals, but also the themes and subjects of development produced by society are passed on to individuals. In addition, it focuses on the values, knowledge, skills and insights that individuals need to stay in the learning process throughout their lives (Chen, 2015). It keeps the individual's curiosity and interest alive and encourages the individual to be willing to seek new information. Thus, it allows the individual to adapt to the innovations that occur both in society and in the business world and to be effective in all aspects of life (Akkuş, 2008). Lee (2008) stated that individuals involved in lifelong learning activities often lead self-controlled lives with higher confidence, open-mindedness, greater awareness of volunteerism for others, and greater positivity and activity. Lifelong learning has emerged as a response to the needs of society, which is trying to keep up with the conditions of the age. The depth and continuity of social change also led to very significant changes in the nature of schooling, and teachers contributed to the change in education (Coolahan, 2002). In terms of teacher training, lifelong learning is also one of the core missions of all educators in providing maximum benefit to their students (Day, 1999). As the functioning of educational systems is generally slow, it takes a long time for teacher training to occur. Thus, it is not enough for teachers to be informed about lifelong learning policies (Coolahan, 2002). Therefore, teachers can prepare their students for Lifelong Learning by promoting various teaching-learning methodologies and increasing their lifelong learning practices and capacities. Teachers should be aware of the importance of lifelong learning in their daily lives in order to encourage their students on lifelong learning. Today, when educational content, technology and many achievements in current life are changing rapidly, it seems important for educators to develop themselves and continue their lifelong learning in order to keep up with this change.

In the core of education, main challenges are solving problems, promoting individual and social development, social interaction, producing collaborative projects and associating education with life. Based on this point, lifelong learning is seen as an opportunity for teachers to increase their personal equipment and increase their knowledge. Teachers also come across epitomes of lifelong learning to reflect the development of professional development and qualifications to society (Dută \& Rafailă, 2014). 


\section{Purpose of Research}

Based on the information provided, the study is aimed to reveal the views of education employees with graduate education on lifelong learning. This research is of great importance in terms of the findings it presents and the awareness it creates about lifelong learning, which is indispensable in today's world, where learning is not sufficient with education received in formal educational settings.

\section{METHOD}

In this section, information about the research model, study droup, data collection tools and data analysis are presented.

\section{Research Design}

The case study design, one of the qualitative research designs, is used in the study. Case research is a research method that works with a current phenomenon within its own real life framework, when the boundaries between the phenomenon and its content are not clear, and when there is more than one source of evidence or data (Yıldırım \& Şimşek, 2019). Case studies are an investigative research pattern that allows in-depth research on a particular subject (Starman, 2013). This study has been prepared as a case study with the aim of comprehensively examining attitudes, experiences and solutions to lifelong learning.

\section{Study Group}

The working group of the research is composed of academicians of Van Yuzuncu Y1l University and teachers with graduate education working in Van province. In the study, it is decided to work with this sample group, assuming that richer and higher-level data would be obtained from academics and individuals with graduate education. In the sample of the study, the method of purposeful sampling is used. Purposeful sampling is a method used to identify situations and people who have knowledge and experience about a particular area of interest or concept (Palinkas et al., 2013). In this context, the opinions of a total of 15 educators, including 1 professor, 2 associate professors, 2 research assistants, 5 faculty members and 10 teachers who have studied at the graduate level, have been taken. Demographic information of the educators participating in the study is given in Table 1. 
Opinions of Academicians and Teachers on Lifelong Learning

\section{Table 1}

Demographic Distributions of the Participants

\begin{tabular}{lll}
\hline \multicolumn{1}{c}{ Variable } & \multicolumn{1}{c}{ Level } & f \\
\hline Gender & Female & 3 \\
Age Range & Male & 12 \\
& $21-30$ age & 2 \\
& $31-40$ age & 11 \\
& 41 age and older & 2 \\
Professional Seniority & $1-5$ year & 2 \\
& 6-10 year & 5 \\
& $11-15$ year & 5 \\
Graduate education status & 16 year and up & 3 \\
& Master without thesis & 3 \\
& Master of science with thesis & 6 \\
Title & PhD & 6 \\
& Academician & 5 \\
\hline
\end{tabular}

It is seen at Table 1, that the majority of the participants in the study are men (12), 11 of the total 15 people participating in the study are in the range of $31-40$ years, and the seniority of these educators is more in the range of 6-10 years and 11-15 years (5 people in each group). Also, 3 of the educators involved in the study have a master's education level without a dissertation, 6 have a master's education level with a dissertation, and 6 have a $\mathrm{PhD}$ level. Finally, another demographic information seen in Table 1 is that 5 of the participants work as academicians and 10 as teachers.

\section{Data Collection Tool and Process}

The data was obtained using a semi-structured interview form prepared by researchers with expert opinions and pre-applied. During the preparation of the interview form, open-ended questions were created in which academics and teachers could express their views on different aspects of lifelong learning (what the concept is, its sustainability, its effects, problems experienced in lifelong learning and suggestions for solutions to this issue). The opinions of three field experts (from the fields of Educational Sciences, primary classroom teaching and Turkish Language Teaching) were taken for the questions in the interview form. In consequence of expert opinion, necessary corrections were made by taking into account feedback and recommendations. In line with the corrections, questions 
that participants could not express their ideas about lifelong learning were removed from the interview form, some questions were corrected in terms of intelligibility and expression, and the interview form was finalized. The interview form consists of 6 open-ended questions in addition to questions related to the demographic information of the participants.

Data of the research was collected from academicians and teachers who volunteered to participate in the research in the province of Van in the 2020-2021 academic year. Due to the lack of appropriate interview conditions due to the covid-19 outbreak, the opinions of 10 teachers and 5 academics were received in writing via e-mail.

\section{Data Analysis}

In this study, descriptive analysis technique was used in the analysis process of the data. At the descriptive analysis stage, different themes are created for qualitative data, existing data is sorted according to predefined themes and commented by creating descriptions (Yildirim \& Simsek, 2019). In this study, topics were determined using interview questions and the data were organized according to the topics. The themes have been created in accordance with the questions in the interview form. In addition, the data of the research were presented by quoting directly to reflect the expressions of the participants in the study clearly. Information about the method and questions of the research was given to determine the external reliability of the research. The researchers tried to ensure internal security by encoding the study's data separately. As a result of the calculation made according to the reliability formula [reliability=consensus/(consensus+dissensus)] put forward by Miles and Huberman (1994), the ratio of compliance between the different coding performed by the researchers was $94 \%$. According to this result, it can be said that the reliability of the codings made is sufficient.

\section{FINDINGS}

In this study, which is aimed at revealing the views of teachers and academicians on lifelong learning, the findings of educators' answers to interview questions are discussed in this section.

\section{Findings for answers to the first research question}

In the study, firstly participants were asked the question "What does the concept of lifelong learning mean for you?" In this question, participants highlighted the themes of continuing education throughout life without 
interruption, continuous development, openness, keeping up with developments, continuous development and continued learning from the cradle to the grave. Examples of the answers to this question are as follows:

A2: Lifelong learning is a flexible learning that lasts a lifetime, which can be done in different places and times that allow us to keep ourselves up to date with innovations or acquire new knowledge and skills.

A3: It is the ability of the individual to participate in learning activities throughout his or her life and equip himself or herself with better skills in all areas necessary.

A5: I define lifelong learning as a learning process that continues from birth to death and also exists in all areas of life.

T2: There is time to learn, there's no process. It means continuity is mandatory.

T3: To continue personal development throughout life, to learn, to read, to continue activities such as understanding.

T5: Lifelong learning means that learning should happen at every moment of life, not just at a certain time. Learning is a process that continues from the cradle to the grave.

T9: It is a concept that breaks down the understanding that limits learning to school and shifts it out of school and adopts the maintenance of it from the cradle to the grave for life.

\section{Findings for answers to the second research question}

In the study, participants were asked the second question, "What are the factors that require lifelong learning?" Educators have been seen to be able to keep up with the rapid developments in the information age, increase cultural interactions, self-realization, technological developments, specialization, human desire to learn continuously and scientific developments are the factors that require lifelong learning. Examples of the answers given to this question are as follows:

A1: Technology, epidemics, lives, cultural interaction, selfrealization...etc..

A2: To be able to follow innovations, to stay up to date in developing life, to acquire new knowledge and skills, to acquire hobbies, to socialize. 
T4: The development of technology, the facilitation of the elimination of needs, the shortage of time of working couples and the consequences of this and similar factors.

T5: I think, factors that require lifelong learning; life conditions are progressing very quickly today, especially given that we are in the age of technology, new information new technologies new ideas are emerging every day, keeping up with this change is the biggest factor.

T8: Specialization, skill acquisition, necessity, conditions of the age, professional necessity.

T9: In today's society, it is necessary to educate individuals who can adapt more quickly to changing living conditions and technology. Education is continuous process without being confined to school age, the absence of an upper limit of learning and developing abilities makes lifelong learning necessary in every moment and area of life.

T10: In a changing world, people cannot be expected to remain constant and remain without self-improvement. Increasing technological advances and changes also require people to learn to develop themselves in a mandatory way, to access new information, to apply this information that they have learned in their lives. However, the world moves forward, individuals cannot be expected to fall back.

\section{Findings for answers to the third research question}

The third question of the study is "What can a teacher do for his personal development within the scope of lifelong learning?" Educators participating in the study stated that teachers can follow new methods and techniques in education within the framework of lifelong learning, complete the subjects they lack, contribute to technopedagogic development, learn foreign languages, develop themselves socio-culturally and advance their professional development. Some sections of the answers to this question are as follows:

A2: He/she can complete his/her shortcomings in areas that he/she thinks are missing. Learn new approaches, methods and techniques related to education.

A4: By receiving various in-service trainings, it is necessary to renew, change and advance himself/herself in his/her field.

T5: I think that a teacher should develop professionally, advance his/her general culture and update his/her knowledge with innovations in his/her field in 
parallel with changing living conditions, social structure and developments in his/her field.

T8: Helshe can improve himself/herself by following courses in professional, social and cultural terms. Not only should he/she learn in these courses, but he/she should transfer them to his/her professional life. It is not enough for a teacher to develop himself/herself not only professionally, but also to have intellectual knowledge in social and cultural terms because the teacher is the role model of the society by the ocuupation he/she performs. It provides education by carrying out a transfer in social and cultural sense with academic knowledge teaching.

T9: He/she can participate in courses and professional development modules in different disciplines that will contribute to the change and development of personal and professional competencies, create awareness, and in accordance with learning needs and desires.

T10: The Ministry of Education offers new courses for the personal development of teachers day by day along with technological advances in educational activities. As the limit of time and space is removed along with lifelong learning, taking these educational activities allows us to improve ourselves as teachers. As part of lifelong learning, as teachers, we can develop by reading by conducting research according to our interests or writing our thoughts about what we have learned.

\section{Findings for answers to the fourth research question}

The question "What are the social effects of lifelong learning?" constitutes the fourth question of the research. Increasing the level of education of society, ensuring access to education for those who are disadvantaged in education, respect for differences, increasing socialization and technological adaptation, social development can be achieved by providing the dissemination of theoretical knowledge into practice are the topics in the statements that participants put forward as the social consequences of lifelong learning. Examples of answers to this question are as follows:

A1: Cohabitation, respect for differences, socialization...

A2: It gives an opportunity to increase the level of education, knowledge and skills of the society. It can introduce education to those who are deprived of education. It can enable people with whom it acquires new professional skills to have a job or increase their income. 
A4: I believe that when lifelong learning occurs, all segments of society will develop in a cognitive, mental, emotional and cultural sense.

T5: Considering that society and the individual are a whole, individuals who develop themselves in the face of new information that is updated every day therefore affect and develop society. As a result, society develops into a dynamic structure that is not stagnant.

T7: I think that the person who learns, questions, investigates, and the person who continues this throughout his life makes and applies decisions that can also observe the benefit of society.

T8: Professional, social, cultural, art, etc. in many areas, individuals develop themselves, deepen their existing knowledge/skills, acquire new knowledge/skills, and affect society in the context of the transfer and continuity of these acquired knowledge and skills. Thanks to these knowledge and skills, individuals become more specialized in their profession or have a job. In this way, the quality of the service received by the society increases, and even if the person has a job, they contribute to employment.

T9: Information societies need individuals with lifelong learning skills. Flexible, diverse, lifelong learning opportunities that integrate the needs of society with the requirements of the age, combine theory and practice, give the individual knowledge and skills that can be passed on to life, provide a great contribution to the development of the individual, as well as to the awareness of society.

T10: The development of a person is the development of society. Society develops when people individually try to learn and develop themselves. With lifelong learning, time and effort are spent on learning, and success is achieved as a result of this effort. Achieving success increases motivation in individuals. Increasing motivation also allows more well-being in society to educate more gifted and happier individuals.

\section{Findings for answers to the fifth research question}

The fifth question posed to educators in the study is "How do technological advances affect lifelong learning?". In their answers to this question, the participants emphasize the themes that technology makes lifelong learning mandatory and inevitable, that learning will be easier with simulation trainings offered by technology, that it is important to reach accurate information, that lifelong learning is independent of time and space thanks to technology, that it is very important for lifelong learning if the technology is used correctly, and that 
it facilitates access to information. Some sections of the answers to this question are as follows:

A2: Life-long learning environments are also changing with technological advances. Distance learning tools will both increase the audience to be reached in lifelong learning and reduce the cost. In addition, the simulation facilities offered by the technology will facilitate difficult or costly training.

A3: Technological developments make lifelong learning mandatory and inevitable. Everything is influenced by technology, especially education, economy, culture and social life. Therefore, technological developments and lifelong learning are closely related.

A4: I think that lifelong learning would have been disrupted, especially if it weren't for technology today. Internet, computer, tablet, etc. I think that thanks to technological elements, everyone can receive various trainings in their target areas without time and space restrictions.

A5: Access to information becomes easier. Just as the speed and amount of information is constantly improving, information is becoming outdated at the same speed. This, in turn, makes lifelong learning necessary.

T2: Technology provides convenience in accessing information and has a big role to play in corrupting information. Therefore, control of technology is essential.

T4: Technology facilitates lifelong learning, and the ability to bring people closer to what they want to achieve is a major privilege.

T5: We can say that technological advances are perhaps the reason for lifelong learning. Technological advances have made lifelong learning mandatory.

T8: It affected in two ways. First, it is necessary to conduct trainings at the point of integration of technological developments into the performed profession. Individuals have gained the skills to integrate technological developments into their profession through the trainings they receive within the scope of lifelong learning. The second is that lifelong learning trainings are delivered to more people independently of time and space through distance learning.

T9: Technology is not a choice but a necessity in our lives. I believe that we are its master, not its prisoner; as long as we use it when necessary, as much as necessary and as necessary, it will bring maximum benefit to all lifelong learning activities. 
T10: It affects a lot. In fact, technological advances are at the center of the concept of lifelong learning. Especially with the pandemic process, online trainings and computer use in our lives have increased immensely. We were able to take courses we hadn't taken before. We taught online. With technology, we can meet people on a flight from one end of the world to the other and get the training you want and we can improve ourselves.

\section{Findings for answers to the sixth research question}

As a sixth question to the participants in the study, "what should be done to ensure that lifelong learning is sustainable and has widespread impact?"the question has been asked. In this question, the educators who participated in the research emphasized the themes of digital ethics, adaptation to digitalization, development of social policies, the availability of lifelong learning activities, facilitating daily life of the trainings given, contributing to the employment of the information to be learned, keeping the learning requests of individuals active, increasing distance education activities, carrying out teaching activities that prioritize individual learning and flexibility, and increasing the number of lifelong learning centres. The examples of the answers given to this question are as follows:

A1: Adapting to the digital age, digital ethics, having ethics of social life, developing top thinking skills, etc...

A3: Social policies should be developed, lifelong learning activities should be achievable and encouraged.

A4: Since we are in the age of science and technology, I think that education should be further opened through distance education.

T1: The knowledge and learning should contribute to the employment process in particular.

T3: A state order based on the merit system is required. Because people always ask "Okay, I've been educated but what good is it going to do? This situation poses a big problem. The incentive should increase. Culturally, learners should be given the privileges that learning gives/ provides.

T4: I think that the more convenience and efficiency the trainings provide in people's daily lives, the wider the range of impacts.

T6: In order for lifelong learning to be sustainable, individuals should have a desire to learn in themselves. Cooperation with various institutions can be made. Public education centres should be actively involved in the process. 
T7: Individuals must first be willing to do so. Good examples biographies of people who have discovered their passions and hobbies after a certain age should be presented as a public spotlight.

T8: As described in the previous question, more people can be reached through distance learning programs. Protocols can be signed with public institutions. Trainings should be carried out in a theory+practical way. A tracking system can be installed. Thanks to the tracking system, plans can be made for the training that will be carried out in the future with the status of individuals receiving training and the feedback received from them.

T9: All kinds of non-formal education opportunities based on the adoption of lifelong learning understanding can be developed in society. According to our existing education program, a more flexible, local, individual learning oriented curriculum can be created. Especially for young people who cannot enter the university, skills and vocational training activities can be increased in a short way. All kinds of activities of local administrations, voluntary organizations and the private sector can be encouraged.

T10: Studies can be carried out on the positive aspects of technology. For example, there may be teachers who do not know how to use a computer yet. Teachers may be offered the opportunity to improve themselves in this regard. Even that's actually lifelong learning. Language courses can be offered in institutions. Because unfortunately, the vast majority of people in Turkey may fail in the second language.

\section{DISCUSSION, CONCLUSIONS AND RECOMMENDATIONS}

In this study, which has tried to reveal the views of graduate education employees on lifelong learning, a total of 15 educators were interviewed, including 5 academicians and 10 teachers with postgraduate education.

At the end of the study, it has been concluded that educators made sense of lifelong learning as continuing education throughout life without interruption, being open to continuous development, keeping up with developments, continuous development and continuing to learn from cradle to grave. When we look at the expressions of the participants that make sense of lifelong learning, it is seen that these expressions coincide with the definitions of lifelong learning in the field (Council of the European Union, 2021; MEB, 2018; Aycicek \& Yanpar Yelken, 2016; Aksoy, 2013; Rasmussen, 2014; Klug et al., 2014; Diker-Coskun \& Demirel, 2012; Dunlap, 2005). In other words, compared to the literature, it can be said that the participants' knowledge levels for the concept of lifelong 
learning are at a good level. Demirel and Yagci (2012) also reached similar results with this study by showing that participants have no misconceptions about the current importance of lifelong learning, the meaning of this concept and lifelong learning. In contrast to this study, Cogmen and Koksal (2014) concluded that teacher candidates could not explain the concept of lifelong learning and did not define the concept well. Demirel and Dos (2019) in their study with police, found that the lifelong learning tendencies of police officers are moderate. The fact that the people involved in the study had graduate education, continued their development and internalized lifelong learning suggests that the participants may indicate a high level of awareness for this concept.

Educators have stated that the ability to keep up with rapid developments in the information age, the increase of cultural interactions, self-realization, technological developments, specialization, a person's constant desire to learn and scientific developments are factors that make lifelong learning necessary. Beycioglu and Konan (2008), Duman (2007) also emphasized that lifelong learning is necessary to keep up with the rapid changes experienced today in parallel with the results achieved in our study. In their study Scout and Koc (2012) and Kilic (2014) with teacher candidates, they demonstrated similar factors that give rise to the lifelong learning needs needed in the information age. Gunes and the Deveci (2020: preface), emphasizes

"In order to learn and learn, it is necessary to develop language skills such as reading, writing, mathematics, information and communication technologies. Developing skills such as critical thinking, creativity, entrepreneurship, problem solving, decision making, and emotion management is also important in this process. To develop the skills of the future, to be successful, we have to learn throughout our lives and constantly improve ourselves"

21.changes in the century have led to the need for well-educated individuals in social, economic and intellectual terms. In this sense, it can be said that the educators participating in the research also emphasize the expressions mentioned as factors that require lifelong learning.

Educators who participated in the study stated that teachers can follow new methods and techniques in education within the scope of lifelong learning, complete the subjects they are missing, contribute to their techno-dogogic development, learn foreign languages, develop themselves socio-culturally and advance their professional development. Kogce et al., (2014) according to the opinions of the instructors, teachers can develop themselves throughout life in parallel with the results reached in our study; Selvi (2011) also reached similar results with this study by stating that teachers can educate students according to 
the needs of the age by renewing themselves according to the needs of the age in a way that will last a lifetime. Also, the results obtained in the studies were Izci and Koc (2012), Gun et al., (2012) and Dogan and Kavtelek (2015) in parallel with the results achieved.

In the study, educators used lifelong learning as a social impact; they stated that social development can be achieved by increasing the level of education of the society, ensuring access to education for those who are disadvantaged in education, increasing socialization and technological cohesion, respecting differences, and putting theoretical knowledge into practice. It is seen that participants emphasize that social development can occur with an increase in the level of education in general. Looking at the literature, the results achieved in our study ensure social integration of lifelong learning (Güleç, Çelik \& Demirhan, 2012), form the basis of social progress( Güneş \& Deveci, 2020), socialize society through leisure activities (Canatan \& Boz, 2019; Kalaycığlu, 2012), increases the quality of society's human resources and employment (Aksoy, 2013), socioeconomic level, age, time, place, eliminating the limitations on concepts such as level of education that offers equal opportunity to every individual (Dinevski \& Dinevski, 2004) that expresses studies showed similarity with that observed. Therefore, it is possible to say that education should not only be given in schools and at school age; it should be acquired everywhere and at any age in the name of social development.

According to the results obtained in the research, educators have demonstrated the effect of technology on lifelong learning by emphasizing the themes that technology makes lifelong learning mandatory and inevitable, that learning will be easier with simulation trainings offered by technology, that it is important to achieve accurate information, that lifelong learning is independent of time and space thanks to technology, that it is very important for lifelong learning if technology is used correctly, and that it facilitates access to information. Technology literacy is one of the main skills emphasized as $21 \mathrm{st}$ century skills in today's world, where technology is developing rapidly and increasing its impact in educational systems and educational materials day by day. With the development of technological opportunities in the information age, the student needs to internalize technology literacy very well in order to test the accuracy of the information they can access and how he/she can access it using technological facilities. Considering that technology is evolving and changing day by day, individuals need to constantly improve themselves, which is where the element of lifelong learning comes up. It can be said that the individual who renews himself and learns for life can increase the level of knowledge independently of time and space by using methods such as inverted learning, 
online learning environments, MOOCs, augmented reality applications, virtual reality applications that emerge by taking advantage of technological opportunities in the age of information and technology without being behind time. Similar to the results reached in the study, many studies (Gunes \& Deveci, 2020; Kaya, 2020; Canatan \& Boz, 2019; Salleh et al., 2019; Samanci \& Ocakc1, 2017; Kogce et al., 2014; Kilic, 2014) will be seen to emphasize that advances in technology lead individuals to learn throughout life and that the two elements are intertwined.

In the study, the educators who participated in the study emphasized the themes of digital ethics, adaptation to digitalization, development of social policies, the availability of lifelong learning activities, facilitating daily life of the trainings given, contributing to the employment of the information to be learned, keeping the learning requests of individuals active, increasing distance education activities, carrying out teaching activities that prioritize individual learning and flexibility, increasing the number of lifelong learning centres as things to be done to make lifelong learning sustainable and increase its widespread impact. Emphasizing that innovations and new methods in education should be developed and designed according to the needs of the age, Turan (2005) also states that the way to achieve this will be possible by making lifelong learning sustainable.

Academicians and teachers who participated in the study define lifelong learning as a process that cannot be removed from an educator's life and renews itself. All participants in the research stated that they are in the process of lifelong learning and that this process should be explained in detail to all segments of society. All participants agree that technology and changing living conditions should be included in the lifelong learning process and that this learning should be facilitated by spreading to a wider range.

Based on the findings obtained, it was seen that the educators who participated in the study generally took a positive attitude towards the sustainability of lifelong learning and demonstrated that the social and individual effects of lifelong learning can be further enhanced with educational support, and that steps should be taken to ensure that developments in technology are also used in educational environments. All individuals in society, except teachers and academics, should also remember that lifelong productivity and lifelong learning literacy are linked and it should be made sense of with the term lifelong learning literacy (Butler, 2012).

In this context, it is important to take steps to ensure that individuals have the skills of the age by raising awareness about lifelong learning in accordance with the needs of the 21st century in our country, and to gain "lifelong learning 
literacy" in order to realize the relevant learning by being aware of which learning types will be carried out according to the needs of individuals for all development.

\section{REFERENCES}

Akkuş, N. (2008). Evaluation of PISA 2006 Results as an Indicator of Lifelong Learning Skills in Terms of Turkey. Unpublished master's thesis, Hacettepe University Institute of Social Sciences.

Aksoy, M. (2013). Lifelong learning as a concept and the European Union adventure of lifelong learning. Bilig, 64, 23-48.

Ayçiçek, B. \& Yanpar Yelken, T. (2016). Examination of lifelong learning competencies and life-wide learning habits of teachers in educational faculties. Journal of Mersin University Faculty of Education, 12(3), 872884.

Beycioğlu, K. \& Konan, N. (2008). Lifelong learning and European education Poly-tikas. Electronic Journal of Social Sciences, 7(24), 369-382.

Burman, N.J., Boscardin, C.K., \& Van Schaik, S.M. (2014). Careerlong learning: Relationship between cognitive and metacognitive skills. Medical Teacher, 36, 715-723.

Butler, J. G. (2012). A History of Information Technology and Systems. University of Arizona.

Can, T. (2011). The Use of Strategies in English Language Learning Coursebooks in the Context of Life-Long Learning. Doctoral dissertation, Istanbul University Institute of Social Sciences.

Canatan, U. \& Boz, H. (2019). The role of participation in lifelong learning activities in supporting active aging. Turkish Studies Social Sciences, 14(3), 343-363.

Candy, P. C. (2003). Lifelong Learning and Information Literacy. Report for U.S. National Commosion on Libraries and Information Science and National Forum on Information Literacy.

Chen, Z. (2015). The analysis and researching on the essences of the lifelong education, lifelong learning and learning society. Scholarly Research Journal for Humanity Science and English Language, 2(10), 2608-2614. 
Coolahan, J. (2002). Teacher education and the teaching career in an era of lifelong learning, OECD Education Working Papers, No. 2. OECD Publishing.

Council of The European Union (2021). Key competencies for Lifelong Learning. https://op.europa.eu/en/publication-detail/-/publication/297a33c8-a1f311e9-9d01-01aa75ed71a1/language-en, Access date: 04.05.2021.

Çöğmen, S. \& Köksal, N. (2014). University opportunities that support the professional development of teacher candidates. Journal of The Faculty of Education of Pamukkale University, 35(1), 85-98.

Day, C. W. (1999). The role of higher education in fostering lifelong learning partnerships with teachers. European Journal of Education, 33(4), 419432.

Demirel, M. \& Yağc1, E. (2012). Classroom teacher candidates ' perceptions of lifelong learning. Journal of Hacettepe University Faculty of Education, Special Issue 1, 100-111.

Diker Coşkun, Y. \& Demirel, M. (2012). Lifelong learning trends of college students. Journal of Hacettepe University Faculty of Education, 42, 108120.

Dinevski, D. \& Dinevski, I. V. (2004). The concepts of university lifelong learning provision in Europe. Transition Studies Review, 11(3), 227-235. https://doi.org/10.1007/s11300-004-0014-z.

Doğan, S. \& Kavtelek, C. (2015). Lifelong learning the perceptions of institution managers about lifelong learning. Journal of The Faculty of Education of Abant Izzet Baysal University, 15(1), 82-104.

Duman, A. (2007). Adult Education. Utopia Publishing House.

Dunlap, J.C. (2005). Changes in students' use of lifelong learning skill during a problem-based learning Project. Performance Improvement Quarterly, 18(1), 5-33.

Dută, N. \& Rafailă, E. (2014). Importance of the lifelong learning for professional development of university teachers - needs and practical implications. Procedia - Social and Behavioral Sciences 127, $801-806$.

Güleç, İ., Çelik, S. \& Demirhan, B. (2012). What is lifelong learning? An assessment of the concept and its scope. Sakarya University Journal of Education, 2 (3), 34-48. 
Güneş, F. \& Deveci, T. (2020). Adult Education and Lifelong Learning. Pegem Academy.

Günüç, S., Odabaşı, H. F., \& Kuzu, A. (2012). Factors affecting lifelong learning. Gaziantep University Journal of Social Sciences, 11(2), 309-325.

İzci, E. \& Koç, S. (2012). Evaluation of teacher candidates' views on lifelong learning. Journal of Social Sciences, 5(9), 101-114.

Jarvis, P. (2004). Adult Education and Lifelong Learning: Theory and Practice. Routledge Falmer. https://doi.org/10.4324/9780203561560

Kalaycioğlu, S. (2012). Proceedings of the Symposium "Intergenerational Solidarity and Active Aging” on 18-24 March 2012 Respect for the Elderly Week. Grafer Design Printing Packaging.

Kashinath, K.S. (2013). Lifelong learning. Scholarly Research Journal for Inter disciplinary Studies, 1-8.

Kaya, K. (2020). Examining the lifelong learning tendencies of sport sciences faculty students. Journal of Education and Learning, 9(3), 99-105.

K1lıç, Ç. (2014). Perceptions of teacher candidates for lifelong learning. Journal of Education and Training Research, 3 (4), 79-87.

Klug, J., Krause, N., Schober, B., Finsterwald, M., \& Spiel, C. (2014). How do teachers promote their students' lifelong learning in class? Development and first application of the LLL Interview. Teaching and Teacher Education, 37, 119-129.

Köğce, D., Özpınar, İ., Şahin, S. M. \& Yenmez, A. A. (2014). Teaching staff's views on learning standards of the 21 . century and lifelong learning. Dicle University Journal of Ziya Gökalp Education, 22, 185-213.

Lee, H. (2008). University continuing education for lifelong learning in Korea. Journal of Adult and Continuing Education, 14(2), 190-202.

MEB (2018). Ministry of Education Lifelong Learning Institutions Regulation. Official gazette dated 11 April 2018 and numbered 30388.

Miles, M. B. \& Huberman, A. M. (1994). Qualitative Data Analysis. Sage Publications Inc.

Özden, Y. (2002). New Values in Education. Pegem A Publishing. 
Palinkas, L. A., Horwitz, S. M., Green, C. A., Wisdom, J. P., Duan, N. \& Hoagwood, K. (2013). Purposeful sampling for qualitative data collection and analysis in mixed method implementation research. Administration and Policy in Mental Health and Mental Health Services Research, 42, 533-544.

Poyraz, H. \& Titrek, Ö. (2013). Development of lifelong learning in Turkey. Abant Izzet Baysal University Faculty of Education Journal, 13(1), 115131.

Rasmussen, P. (2014). Lifelong learning policy in two national contexts. International Journal of Lifelong Education, 33(3), 326-342.

Salleh, U. K. M., Zulnaidi, H., Rahim, S. S. A., Zakaria, A. R., \& Hidayat, R. (2019). Roles of self-directed learning and social networking sites in lifelong learning. International Journal of Instruction, 12(4), 167-182. https://doi.org/10.29333/iji.2019.12411a

Samanc1, O. \& Ocakc1, E. (2017). Lifelong learning. Journal of Bayburt Education Faculty, 12 (24), 711-722.

Selvi, K. (2011). Teachers' lifelong learning competencies. IJOCIS, 1(1), 61-69.

Smith, C. M. \& Pourchot, T. (1998). What does educational psychology know about adult learning and development? In C. M. Smith \& T. Pourchot (Eds.), Adult Learning and Development: Perspectives from Educational Psychology (pp. 3-10). Lawrence Erlbaum Associates, Publishers.

Starman, A. B. (2013). The case study as a type of qualitative research. Journal of Contemporary Educational Studies, 1, 28-43.

Turan, S. (2005). Lifelong learning in European Union education policies towards learning societies. Journal of European Studies, 5(1), 87-98.

Yıldırım, A. \& Şimşek, H. (2019). Qualitative Research Methods in Social Sciences. Seçkin Publishing. 


\section{EXTENDED ABSTRACT}

Purpose: Lifelong learning, which is often cited in Turkey with the transition to the 21st century, is a concept that puts people in the spotlight, erodes the understanding that limits learning in school, takes it outside of school and takes skills, knowledge and skills from cradle to grave. Lifelong learning encompasses all learning activities that enable them to develop in a civic, social and employment related style. These actions can be formal, informal, or natural. In the constantly and rapidly changing modern world, formal education may be insufficient in terms of content and form to meet the needs of contemporary society. One way to close this gap is to increase interest in lifelong learning through a process that combines formal, non-formal and informal education. Lifelong learning, sometimes called lifelong learning, goes beyond formal education and training and continues individual learning throughout life. In addition to formal education, personal development is also important. For the development of any society, education must continue throughout life and people must continually improve throughout life. This study aims to examine the opinions of academicians and teachers about lifelong learning. We aim that this study will make a great contribution to literature and lead to new studies for researchers. This study is designed to expose the opinions of educators with graduate studies on lifelong learning. This study is of great importance in terms of the conclusions and awareness it provides about lifelong learning, which is indispensable in the modern world and that education is not sufficient with education received in formal educational institutions.

Method: The study used a case study design, one of the high-quality research projects. Case study design is a research method that works with a current phenomenon within its own real life, when the boundaries between the fact and its content are not clear, and when there are multiple sources of evidence or data. The study was prepared as an exemplary study to comprehensively explore approaches, experiences and proposals for solutions that focus on lifelong learning. The research working group comprised of academicians from Van Yuzuncu Y1l University and teachers with postgraduate studies working in Van province. In the study, it was decided to work with this sample group on the assumption that richer and reliable data would be received from people with postgraduate education. In this sense, the opinions of 15 educators were received, of which 1 professor, 2 associate professors, 2 researchers, a total of 5 academicians and 10 postgraduate teachers. In this study, the descriptive analysis method was used in data analysis. In this study, subjects were identified using interview questions, and the data was sorted according to subjects. The topics were created according to the interview form questions. 
Findings: Findings of the study shows us that participants highlighted the themes of continuous education without interruption, openness to continuous development, keeping up with development, continuous improvement and continuous learning from cradle to grave. Therefore, educators have been seen to say that the capacity to keep pace with the rapid development in the information age, the rise of the drug culture, the self, the technological progress, the specialization, the continuous desire to learn and the scientific results are the factors that cause the need for lifelong learning. According to a general consensus of the participant, improving the level of education of society, ensuring access to education for the disadvantaged in education, respect for differences, increased socialization and technological adjustment, social development can be achieved by disseminating theoretical knowledge in practice are arguments in the statements that participants pose the social consequences of continuing education.

Discussion and Conclusion: In the study, it is clearly seen that the opinions of academicians and teachers about lifelong learning match up with each other. In the study it is concluded that educators have a sense of lifelong learning in the form of continuous learning, without interruption, for the entire life, the continuous development is still open, to keep pace with the events, the continuous development and continuous learning, from the cradle to the grave. Educators who participated in the study said that teachers can use new methods and techniques in education as part of lifelong learning, can complement subjects, contribute to the development of technology, learn a foreign language, develop sociocultural and enhance professional development. In this context, it is also important for Turkey to take steps to ensure that people have the skills of old age by raising awareness of lifelong learning in line with the needs of the 21. century. 